\title{
Revealing Benzene, Toluene, Ethyl Benzene, Xylenes (BTEX) Emission at Gas Stations, Case Study in Semarang City
}

\author{
Haryono $S$ Huboyo ${ }^{1, *}$, Irawan $W$ Wardhana $^{1}$, and Auliafika Resminingpuri ${ }^{1}$ \\ ${ }^{1}$ Department of Environmental Engineering, Faculty of Engineering, Diponegoro University, Semarang - Indonesia
}

\begin{abstract}
Evaporation of gasoline at gas stations is the origin of air pollutants in gas station environment. This study is intended to estimate BTEX emission levels at gas stations and mapping BTEX emissions at all gas stations in Semarang. 4.09 D Tank Program with supported data collected by survey and secondary data used to calculate the estimated emissions. We also measured BTEX levels in the gas station location sample with charcoal tubes as adsorbent and PCXR4 mini pump sampler. The emissions from dispensers and storage tanks in gas stations have different emission characteristics. The amount of emissions from dispensers for VOC pollutants is 3.9261 tons/year and benzene is 0.0561 tons/year (case study UNDIP gas station). While the emission from a storage tank for VOC pollutants was 232.91 tons/year, benzene was 1.79 tons/year, toluene was 33.36 tons/year, ethylbenzene was 0.39 tons/year, and xylene was 1.43 Tons/year. The estimation results of the model with the results of direct BTEX measurements in the field showed that the field measurement results were smaller than those estimated. Some assumptions used in the calculations contribute to estimating uncertainty. The measured BTEX concentration still meets the quality standard (Minister of Manpower and Transmigration Regulation No. 13 of 2011).
\end{abstract}

Keywords: air pollution; dispenser; emission; evaporation; fuel; gas station.

\section{Introduction}

Facilities for Fuel Stations or Gas stations (SPBU) have a strategic role in the supply of fuel in urban areas [1]. The criteria for SPBU location should support free mobility and no disruption for vehicle users to obtain fuel. The more numbers of vehicles, it will increase the need for gas stations and as the city grows to a metropolitan area, the number of gas stations will be high. Gas stations are one of the main sources of air pollutant particularly VOC components.

Other sources of VOC emissions are from the oil refining industry, petrochemical industry and paint solvent industry [2]. Evaporation of gasoline at gas stations is the origin of air pollutants in the gas station environment. One of the causes of evaporation is that the pressure on the tank will change during the process of loading and unloading gasoline. Whereas BTEX (Benzene, Toluene, Ethyl Benzene, and Xylenes) are aromatic hydrocarbons which categorized as VOC and HAP (Hazardous Air Pollutant). BTEX concentration values at gas stations are influenced by several factors, including temperature and humidity. Because of its solubility in water, rainfall affects variations in BTEX concentration [3].

Evaporation of fuel occurs in storage fuel tanks and fuel dispensers. Gasoline is very volatile in free air, to prevent evaporation and keep it in a liquid state, then the pressure in the heat tank needs to be given a minimum pressure of 2 bar. While gasoline in the heat tank can be reduced by volatility if a minimum pressure of $1.5 \mathrm{bar}$ is applied [4]. Related to ambient BTEX in the gas station, Correa [5] showed that aromatic concentrations i.e BTEX in ambient air at gas stations are higher than the average values at locations with high vehicle flux. To reduce the BTEX exposition in a gas station area, they suggested the use of vapor-recovery technology for workers during the refueling process at gas stations.

Based on the Minister of Manpower and Transmigration Regulation No.13 in 2011, the ambient air quality standard for Benzene, Toluene, Ethyl Benzene, and Xylene was 0.5 ppm, 50 ppm, 100 ppm, and $100 \mathrm{ppm}$ respectively.

Typical fuel sold at gas stations in Indonesia are naphtha (with the addition of HOMC to obtain RON 88), then High Speed Diesel (HSD), a type of diesel fuel that has a performance number of octane numbers reaching 45. The HSD fuel consists of three types i.e Biosolar, Pertamina Dex, and Dexlite. The third fuel is Pertalite is a new type of fuel oil produced by Pertamina with RON 90 levels that are better than naphtha/premium (RON 88). Besides, Pertalite is a cleaner and more environmentally friendly product. Pertamax is the fourth fuel sold which has RON (Research Octane Number) 92 fuel, this fuel is intended for motorized vehicles that require the use of unleaded and high-octane fuel. Perhaps, the best fuel sold is pertamax plus (RON 95) is a type of fuel intended for cutting-edge vehicles that require the use of high-octane and environmentally friendly fuels

\footnotetext{
Corresponding author: huboyo@gmail.com
} 
The typical components in gas stations are: buried storage tank, quick coupling, hose (a delivery hose from the truck to the storage tank), fillpot (connecting between hose and storage tank), the deepstick house (a fuel height gauge in a storage tank), the PV valve, (connecting channel between the storage tank and outside air, dispenser (fuel distributor from the storage tank to the consumer vehicle).

This study is intended to estimate BTEX emission levels at gas stations and mapping BTEX emissions at all gas stations in Semarang.

\section{Material and Method}

\subsection{Data Collection}

This research was conducted for 6 months, starting from December 1, 2017, to May 31, 2018. The collection of primary data was carried out at 2 gas stations in the city of Semarang. UNDIP gas stations (44-502-23) and Setiabudi gas stations (41-502-20). Then from these data, we expand our typical results to gas stations across Semarang city (Fig.1.)

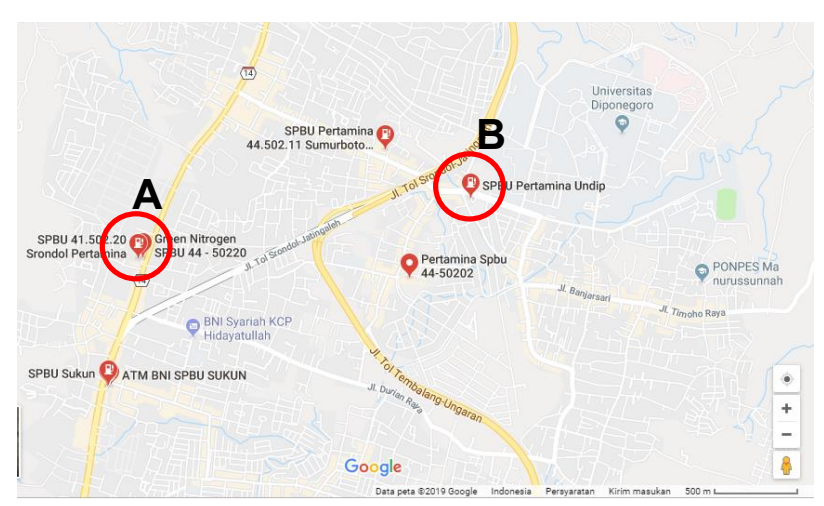

Fig 1. Site Location for Data Collection

We collected data on the number of gas stations, the number of nozzles on dispensers, fuel storage tanks (volumes), fuel tank car ritation, and types of fuel sold at gas stations. We also classified gas stations, number of storage tanks, fuel sales, tank car rites, meteorological data (temperature, wind speed, solar insulation factor), and characteristic of consumer vehicles.

\subsection{Data Analysis}

For estimating the emission i.e Losses in this terminology we used 4.09D TANKS application. This application can be downloaded freely at the website https://www3.epa.gov/ttnchie1/software/TANKS 4.09d/.

4.09D TANKS software has a template for inputting data to make it easier in the data processing. The template contains a data column that must be filled in for the process of running data. The data needed is divided into tank types, information tanks (identification numbers), information fittings, site information (temperature and wind speed), liquid information (fuel types), liquid or component information data fields, then the last one is entering monthly data based on the volume of fuel contained in the tank.

4.09D TANKS 4.0 provides different data entry screens for five different tank types. Types of tanks contained in software options include $4.09 \mathrm{~d}$ Vertical Fixed Roof TANKS, 4.09d Horizontal Fixed Roof TANKS, External Floating Roof Tanks, Internal Floating Roof Tanks, and Domed External Floating Roof. The storage tank at the gas station has a $4.09 \mathrm{~d}$ Horizontal Fixed Roof TANKS.

\subsection{BTEX Measurements for Validation}

Samples are collected in the range from 10.00 to 12.00 AM which is generally the peak hour of the gas station activities. The measurement duration of each sample is 20 minutes with the position of the sampling devices was 1.5 meters above the ground level. Measurements were done using charcoal tubes as adsorbent and PCXR4 mini pump sampler $(0.2 \mathrm{~L} /$ minute flowrate). After sampling, the tubes were evacuated to laboratory analysis. As for the analysis method, all charcoal tubes and standard solutions must be preheated at room temperature before extraction and analysis. The two ends of the charcoal tube are solved to be extracted. Extraction is done by removing the contents of the sorbent in the form of activated charcoal and placing it in a $5 \mathrm{ml}$ vial then adding $2 \mathrm{ml}$ of carbon disulfide solution (CS2) to each vial. Then it is closed using a special cover (Teflon) and shaken for 2 minutes after which it is left for 30 minutes for the agitation process. The samples that were disbursed were then analyzed using GC-MS Agilent Technologies 6890 Gas Chromatograph with Auto Samplerand 5975N Mass Selective Detector and Chemstation data system.

\section{Result and Discussion}

Based on Pertamina regulations [6], the classification of gas stations is based on the area of the gas station, the width of the face of the gas station and the estimated sales volume. Then based on secondary and survey we classify gas station (A Type, B Type, and C Type) based on the district in Semarang city as follows:

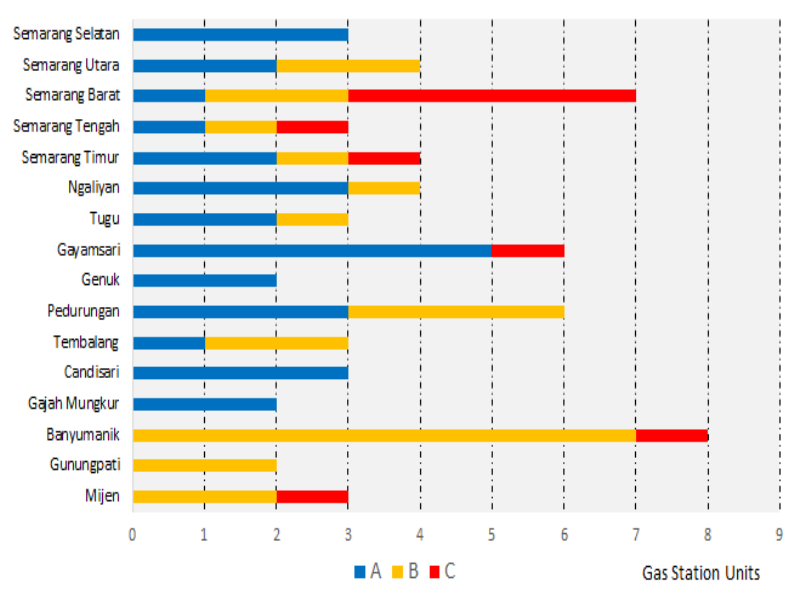

Fig 2. Gas Station Type (A,B,C) Based on District 
Gas stations A Type dominated for all districts. Fuel storage at gas stations has a diverse capacity, ranging from 10,000 to $60,000 \mathrm{~L}$.

Survey Result of vehicle traffic in three gas stations: Two-wheel vehicles traffic in Gas Stations Undip, Setiabudi and Akpol were: 5112, 3991, 5520 respectively. While four-wheel vehicles were 1836 , 1433, 2232 respectively.

By inputting data to TANK 4.09D software i.e Semarang City temperature data in $2017\left(\mathrm{~F}^{\circ}\right)$, wind speed (mph), solar insolation factor (Btu / ft2 day), tank diameter (ft), tank length (ft ), tank capacity (gallons), and RVP value of fuel then based on 4.09D TANKS 4.0 calculation, the total losses (emission) of VOC is listed in Table 1.

Table 1. Emission Estimate of Fuel in Surveyed Gas Station

\begin{tabular}{|c|c|c|}
\hline \multirow{2}{*}{ Fuel } & $\begin{array}{c}\text { SPBU Undip } \\
44-502-23\end{array}$ & $\begin{array}{c}\text { SPBU Setiabudi 41- } \\
502-20\end{array}$ \\
\cline { 2 - 3 } & Ton/year & Ton/year \\
\hline Gasoline/Premium & 1.552 & 1.463 \\
\hline Pertamax & 1.323 & 1.240 \\
\hline Pertalite & 1.657 & 1.364 \\
\hline
\end{tabular}

The example of calculation is following:

『Total Losses)_gasoline $=$

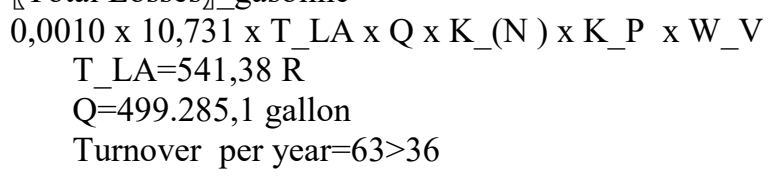

The results of the comparison of benzene and gasoline emissions for the three gas stations based on TANKS 4.0 calculation data can be seen in Fig. 3. The emissions from dispensers are higher for benzene parameters rather than from the storage tank. However, unlike for benzene, for fuel parameters (the premium fuel), the emissions from the storage tank are larger. The recapitulation of the calculation of BTEX emissions based on each district can be seen in the following Fig.4.

(A)

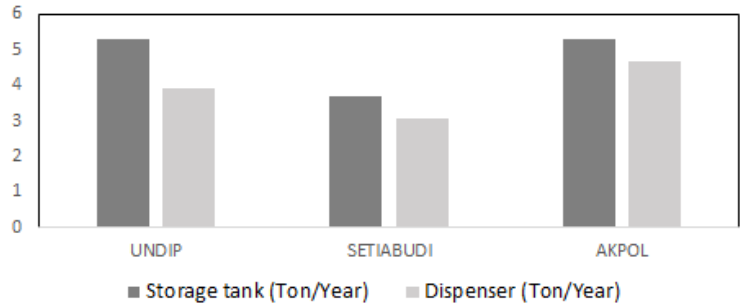

(B)

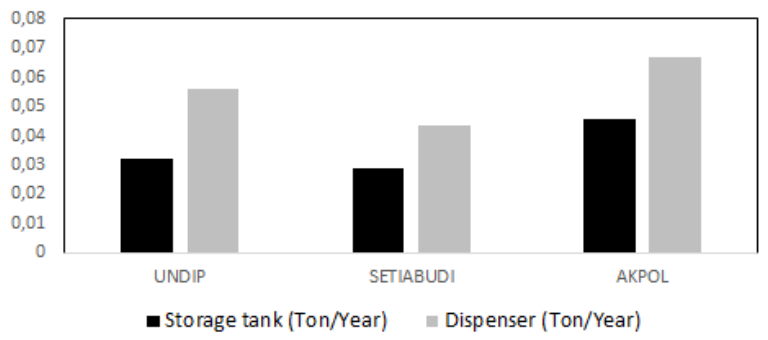

Fig 3. Emission From Storage Tank and Dispenser for Gasoline (A) dan Benzene (B)

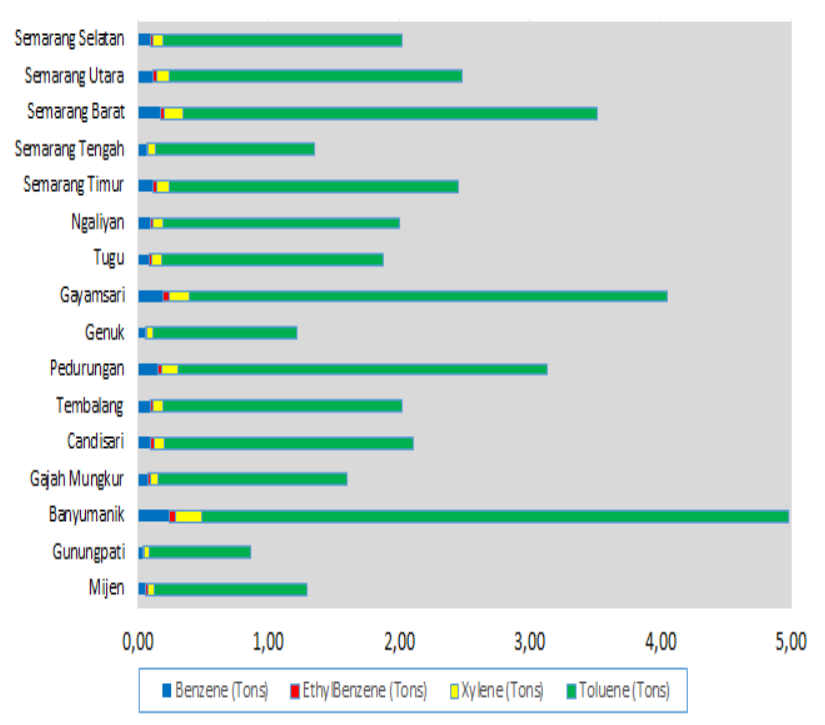

Fig. 4 BTEX Emission Based on District

Emissions in the Banyumanik district are highest because they have the highest number of gas stations. This was followed by the Gayamsari and Semarang Barat districts. The biggest emission is indeed from Toluene because of the biggest emission factor. When compared with BTEX concentrations in other countries, the ambient BTEX concentration is still below the measurement results for example in Thailand the result was around one third for benzene. Whereas when compared with the measurement results in Brazil, the measurement results in Semarang reached 10-fold for benzene. The fuel sold at gas stations is different so the results obtained are also different.

The results of BTEX measurements at three locations of data collection show the results of the estimation of ambient air concentrations around gas stations are greater than those actually measured as shown in Table 2.

Table 2. Mesurement Result of BTEX at Gas Stations (ppm)

\begin{tabular}{|l|c|c|c|}
\hline \multicolumn{1}{|c|}{ Parameter } & $\begin{array}{c}\text { SPBU } \\
44-501-02\end{array}$ & $\begin{array}{c}\text { SPBU } \\
44-502-23\end{array}$ & $\begin{array}{c}\text { SPBU } \\
41-501-20\end{array}$ \\
\hline Benzene & $<0,092$ & $<0,092$ & $<0,092$ \\
\hline Toluene & $<0,058$ & $<0,058$ & $<0,058$ \\
\hline Ethylbenzene & $<0,010$ & $<0,010$ & $<0,010$ \\
\hline Xylene & $<0,017$ & $<0,017$ & $<0,017$ \\
\hline
\end{tabular}

The analysis results show the measurement result tends to be small for all parameters. This can be caused by the position of the measurement device that is not close to the source of emissions, namely the consumer vehicle tank. The position of the tool during the measurement process takes place which is above the fuel dispenser. 


\section{Conclusion}

The emissions from dispensers and storage tanks in every gas station have different emission characteristics. The amount of emissions from dispensers for VOC pollutants (gasoline) is 3.9261 tons/year and benzene is 0.0561 tons/year (case study: UNDIP gas station). While the emission from the storage tank for VOC pollutants was 232.91 tons/year, benzene was 1.79 tons/year, toluene was 33.36 tons/year, ethylbenzene was 0.39 tons /year, and xylene was 1.43 Tons/year. The estimation results of the model with the results of direct BTEX measurements in the field showed that the field measurement results were smaller than those estimated. Some of the assumptions used in the calculations contribute to estimation uncertainty. The measured BTEX concentration is still meet the quality standard (Minister of Manpower and Transmigration Regulation No. 13 of 2011)

\section{Acknowledgment}

The author greatly appreciated to the student who collected data in the field and assisting on the modelling work.

\section{References}

1. A. Moelyanto, I. Bukhori, The Characteristics of Gas Stations Analysis in the Rapidly Developing Area of Southern Semarang City, Undip Press: Semarang (2012)

2. G.G. Pandit, S.K. Sahu, V.D. Puranik, Distribution and Source Apportionment of Atmospheric NonMethane, Atmos. Poll. Res. 2 (2) (2011)

3. P. Rattanajongjitrakorn, T. Prueksasit, Temporal Variation of BTEX at The Area of Petrol Station in Bangkok, APCBEE Procedia 10 (2014)

4. I.M. Astina, Study of Development of Pressurized Circulation Systems in SPBU, Bandung: Prosiding Seminar Nasional Tahunan ke-5 Teknik Mesin (2006)

5. S.M. Correa, G. Arbilla, M.R.C. Marques, K.M.P.G. Oliveira, The Impact of BTEX Emissions from Gas Stations in The Atmosphere. Atmos. Poll. Res. 3(2), 163-169 (2012)

6. PT. Pertamina, Gas Station Location Requirements, spbu.pertamina.com/dashboard/info.html, accessed 7 January 2018 at 03.05 PM (2015) 